\title{
Mulching materials and wetted soil percentages on zucchini cultivation
}

\section{Tratamentos de cobertura do solo e porcentagens de área molhada no cultivo da abobrinha}

\author{
Gustavo Henrique da Silva ${ }^{*}(\mathbb{D})$, Fernando França da Cunha ${ }^{(D)}$, Caio Vieira de Morais ${ }^{1}$, \\ Agnaldo Roberto de Jesus Freitas ${ }^{2}$ (D), Derly José Henriques da Silva ${ }^{3}$ (D) , Caetano Marciano de Souza ${ }^{3}$
}

\author{
1Universidade Federal de Viçosa/UFV, Departamento de Engenharia Agrícola/DEA, Viçosa, MG, Brasil \\ Universidade Federal de Viçosa/UFV, Departamento de Solos/DPS, Viçosa, MG, Brasil \\ 3Universidade Federal de Viçosa/UFV, Departamento de Agronomia, Viçosa, MG, Brasil \\ ${ }^{*}$ Corresponding author: dasilva.h.gustavo@gmail.com \\ Received in March 20, 2020 and approved in May 27, 2020
}

\begin{abstract}
Polyethylene mulch can cause serious problems in the environment. A promising alternative to polyethylene mulch is biodegradable mulch. Therefore, a two-year experiment was carried out with zucchini (Cucurbita pepo L.) during the cropping seasons of 2017 and 2018 in Southeast Brazil to investigate the effects of four soil mulching treatments (white polyethylene mulch: WP, black polyethylene mulch: BP, biodegradable mulch of brown recycled paper: RP and nonmulched: NM) and two wetted soil percentages (50 and $70 \%$ of the soil surface) using a randomized block design with five repetitions. The average water consumption of the zucchini was $157 \mathrm{~mm}$ in the WP treatment, $155 \mathrm{~mm}$ in the BP treatment, $155 \mathrm{~mm}$ in the WP treatment and $215 \mathrm{~mm}$ in the NM treatment. The yield was higher in the WP (78.1 ton ha-1) and BP $\left(69.1\right.$ ton ha $\left.^{-1}\right)$ treatments than in the $\mathrm{RP}\left(66.6\right.$ ton $\left.\mathrm{ha}^{-1}\right)$ or NM $\left(52.4\right.$ ton $\left.\mathrm{ha}^{-1}\right)$ treatments. The daily thermal amplitude was lowest in the RP treatment $\left(3.6-6.0^{\circ} \mathrm{C}\right)$ and highest in the BP treatment $\left(7.3-9.0^{\circ} \mathrm{C}\right)$. The lower wetted soil percentage $(50 \%)$ reduced water consumption (by $\left.5-7 \%\right)$ and improved water-use efficiency (by $11 \%$ ). Weeds, including Cyperus roduntus, were more efficiently controlled in the RP treatment than in the WP and BP treatments. In general, compared to the nonmulched treatment, mulches were effective in reducing weed infestation (95\%), increasing yield (36\%) and improving water-use efficiency (94\%). RP, as an alternative to polyethylene mulch, can save water and control weeds in zucchini crops. These results represent useful information that extends the mulching options for technicians and farmers.
\end{abstract}

Index terms: Biodegradability; Cucurbita pepo; drip irrigation; water saving.

\section{RESUMO}

Mulch de polietileno pode causar sérios problemas ao meio ambiente. Uma alternativa promissora para a mulch de polietileno é o mulch biodegradável. Por isso, um experimento de dois anos foi realizado com abobrinha (Cucurbita pepo L.) durante as safras de 2017 e 2018 no Sudeste do Brasil para avaliar os efeitos de quatro tratamentos de cobertura do solo (mulch de polietileno branco: WP, mulch de polietileno preto: BP, mulch biodegradável de papel reciclado (cor marrom): RP e sem-mulch: NM) e duas porcentagens de área molhada (50 e $70 \%$ da superfície do solo molhada) usando o delineamento de blocos ao acaso com cinco repetições. O consumo de água médio das safras de abobrinha foram $157 \mathrm{~mm}$ em WP, $155 \mathrm{~mm}$ em BP, $155 \mathrm{~mm}$ em WP e $215 \mathrm{~mm}$ in NM. A produtividade foi maior em WP $(78,1$ ton ha-1 $)$ e BP $(69,1$ ton ha-1) de que em RP $(66,6$ ton ha-1) e NM $(52,4$ ton ha-1 $)$. A amplitude da temperatura do solo média foi menor in $\mathrm{RP}\left(3,6-6,0^{\circ} \mathrm{C}\right)$ e maior em $\mathrm{BP}\left(7,3-9,0^{\circ} \mathrm{C}\right)$. A porcentagem de área molhada menor, $50 \%$, reduziu o consumo de água (5-7\%) e melhorou a eficiência do uso da água (11\%). As plantas daninhas, incluindo Cyperus Roduntus, foram controladas de forma eficiente em RP comparado com WP e BP. Em geral, os mulches foram eficientes para reduzir a infestação de ervas daninhas (95\%), aumentar o rendimento (36\%) e melhorar a eficiência do uso da água (94\%) em comparação com sem-mulch. RP é uma alternativa ao mulch de polietileno visando economia de água e controle de plantas daninhas em abobrinha. Em geral, esses resultados representam informações úteis que ampliam as opções para técnicos e agricultores.

Termos para indexação: Biodegradabilidade; Cucurbita pepo; irrigação por gotejamento; economia de água. 


\section{INTRODUCTION}

Zucchini (Cucurbita pepo L.) is an important horticultural crop globally. In Brazil, 135,752 tons of zucchini fruit, equivalent to US \$55.54 million, was produced in 2019 (Prohort, 2019). Zucchini crops are sensitive to water deficits (Contreras et al., 2017) and weeds (Coleman et al., 2015). Because of this, polyethylene mulch is frequently used in zucchini cultivation. Plastic film mulching can control weeds (Coleman et al., 2015), conserve soil moisture and save water by reducing soil evaporation (Liu et al., 2013), modify soil temperature (Ribas et al., 2015), increase irrigation and fertilization efficiency (Biswas et al., 2015; Yang et al., 2015), reduce viruses in fruits (Brust, 2000; Olinik et al., 2011), accelerate leaf area growth (Fan et al., 2017; Qin et al., 2016) and increase yield (El-Samnoudi et al., 2019; Hou et al., 2019).

Polyethylene, a plastic film traditionally used as mulch, is not properly removed from soil (Liu; He; Yan, 2014), not efficiently recycled and is often stockpiled onfarm, burned, or deposited in landfills (Ahokas et al., 2014). Additionally, its residues in soil can affect seed germination, root growth, and soil moisture homogeneity (Liu; He; Yan, 2014) and lead to the formation of environmentally harmful chemical products, such as phthalate esters, di(2-ethylhexyl) phthalate, aldehydes and ketones (Chen et al., 2013). Therefore, biodegradable mulches are suitable alternatives for replacing polyethylene. Biodegradable mulches include paper (cellulosic fiber), polylactic acid, polyester and corn, sugar cane, or potato starch (Gross; Kalra, 2002). Additionally, biodegradable mulches can be broken down by photodegradation or biodegradation (Kasirajan; Ngouajio, 2012), thus reducing the cost of removal and disposal. Reports indicate that yield and weed control are comparable to those obtained with polyethylene mulch in many crops (Brault; Stewart; Jenni, 2002; Cirujeda et al., 2012; Miles et al., 2012; Saraiva et al., 2012; Wortman; Kadoma; Crandall, 2016). However, to be suitable, biodegradable mulches need to be efficient in conserving soil moisture and controlling weeds, mainly in tropical climates.

The use of mulch in association with drip irrigation has been shown to be suitable for the worldwide production of zucchini in both open-field and protected cultivation (Carpes et al., 2008; Coleman et al., 2015), potato (Zhang et al., 2017) and tomato (Biswas et al., 2015). In drip irrigation, a small volume of water is constantly delivered in the root zone, increasing irrigation and fertigation efficiency (Vicente et al., 2017). Mulch types and characteristics of drip irrigation systems can influence the soil water distribution, mainly in the top $0-20 \mathrm{~cm}$ soil layer (Chen et al., 2013), which has the highest concentrations of zucchini roots (Al-Omran et al., 2005; Contreras et al., 2017). Spatiotemporal changes in soil water content can affect evapotranspiration (Zhang et al., 2017). Therefore, the impact of different mulch types and drip irrigation on zucchini water consumption, water saving and yield must be studied.

An essential parameter in drip irrigation system design is wetted soil percentage, which is the area wetted as a percent of the total irrigated area (Keller; Karmeli, 1974). Wetted soil percentages that are too low may cause poor root growth and distribution, resulting in water stress, while wetted soil percentages that are too high may cause poor soil aeration, deep drainage, and high soil evaporation, resulting in low water- and fertilizer-use efficiency and groundwater contamination. Changes in wetted soil percentages require different irrigation frequencies, impacting the soil water regime, which can influence root distribution, solute transport, water uptake by roots and yield (Al-Omran et al., 2005; Feddes et al.,1976; Grecco et al., 2019; Kuslu et al., 2014). Determining a suitable wetted soil percentage could increase yield while conserving water.

Therefore, field experiments during two consecutive cropping seasons in Southeast Brazil were carried out to investigate the effect of different soil mulching materials and wetted soil percentages on water consumption, net photosynthesis, leaf area index, fruit yield and water-use efficiency in zucchini and the ability of the mulches to control weeds.

\section{MATERIAL AND METHODS}

Zucchini (Cucurbita pepo L.) was cultivated in a field experiment at the experimental field of the Department of Plant Science $\left(20^{\circ} 45^{\prime}\right.$ 'S, $42^{\circ} 52^{\prime} \mathrm{W}, 650$ $\mathrm{m}$ a.s.1.), Viçosa, Minas Gerais, Southeast Brazil, in two consecutive cycles in 2017 and 2018. The municipality of Viçosa, belonging to the Zona da Mata mesoregion in Minas Gerais, has an average annual temperature of $21.8{ }^{\circ} \mathrm{C}$, annual precipitation of $1361 \mathrm{~mm}$ and Cwa climate (according to Köppen's classification), which is characterized by humid, subtropical conditions, with dry and cold winters and hot and rainy summers (Alvares et al., 2013).

The experimental area was $432 \mathrm{~m}^{2}$. The groundwater remained at a depth of $\sim 20 \mathrm{~m}$. The local soil was an Argissolo Vermelho (Ultisol), with 390 
$\mathrm{g} \mathrm{kg}^{-1}$ sand, $200 \mathrm{~g} \mathrm{~kg}^{-1}$ silt, and $410 \mathrm{~g} \mathrm{~kg}^{-1}$ clay (clay texture). The soil physical-hydraulic and chemical properties at the surface $(0-20 \mathrm{~cm}$ depth $)$ are described in Table 1. These characteristics were determined before the implementation of the experiments. The composite sample used for all the soil analyses was made of a mixture of several samples from the experimental area (Teixeira et al., 2017).

Two different wetted soil percentages (WSPs; 50 and $70 \%$ ), the ratio between actual wetted soil volume and total soil volume within a specified soil layer (Schwartzman; Zur, 1986), were evaluated using drip irrigation. Four different soil mulching treatments were studied with the two wetted soil percentages: white and black polyethylene mulches (Electro Plastic, São Paulo, BRA), biodegradable mulch of recycled paper (Ponte Nova Papéis, Ponte Nova, BRA) and a nonmulched control. For the mulched treatments, approximately $70 \%$ of the soil surface was covered with mulch, and the edges were buried. Both polyethylene mulches were $22 \mu \mathrm{m}$ thick, and the biodegradable mulch was $187 \mu \mathrm{m}$ thick. A completely randomized block design with six replications was adopted.

Each plot $(3.0 \mathrm{~m} \times 3.0 \mathrm{~m})$ contained 3 rows, 1.0 m apart. Zucchini seeds (cv. PX 7051, Seminis, São Paulo, BRA) were hand-sown every $50 \mathrm{~cm}$ at a depth of $3 \mathrm{~cm}$. For the mulched treatments, holes with a 7 $\mathrm{cm}$ diameter were punched through the film to sow the seeds.

Disk plows, disk harrows and rotary hoes were used for tilling operations 15 days before sowing in both experiments. In the 2017 cropping season (winter/spring), the zucchini seeds were sown in the field on August 19, and harvest was carried out for 26 days, from October 05 to October 31. After sowing, $90 \mathrm{~kg} \mathrm{ha}^{-1} \mathrm{~N}, 100 \mathrm{~kg}$ $\mathrm{ha}^{-1} \mathrm{P}_{2} \mathrm{O}_{5}, 100 \mathrm{~kg} \mathrm{ha}^{-1} \mathrm{~K}_{2} \mathrm{O}, 10 \mathrm{~kg} \mathrm{ha}^{-1} \mathrm{Ca}, 70 \mathrm{~kg} \mathrm{ha}^{-1} \mathrm{Mg}$ and $20 \mathrm{~kg} \mathrm{ha}^{-1} \mathrm{~S}$ were applied through the drip irrigation system (fertigation) on five dates $(20 \%$ on September $01,30 \%$ on September 15, 30\% on September 30, and $20 \%$ on October 15).
In the 2018 cropping season (summer/autumn), the zucchini seeds were sown in the field on February 02, and harvest was carried out for 21 days, from March 27 to April 16. After sowing, $90 \mathrm{~kg} \mathrm{ha}^{-1} \mathrm{~N}, 80 \mathrm{~kg} \mathrm{ha}^{-1} \mathrm{P}_{2} \mathrm{O}_{5}, 80 \mathrm{~kg} \mathrm{ha}^{-1}$ $\mathrm{K}_{2} \mathrm{O}, 10 \mathrm{~kg} \mathrm{ha}^{-1} \mathrm{Ca}, 70 \mathrm{~kg} \mathrm{ha}^{-1} \mathrm{Mg}$ and $40 \mathrm{~kg} \mathrm{ha}^{-1} \mathrm{~S}$ were applied by fertigation on five dates $(20 \%$ on February 15 , $30 \%$ on March $01,30 \%$ on March 15, and $20 \%$ on April $01)$. These nutrients were provided by a combination of calcium nitrate, potassium nitrate, monoammonium phosphate, ammonium sulfate, magnesium sulfate and potassium chloride fertilizers. In both experiments, chlorantraniliprole (Premio-20\%) and azoxystrobin/ difenoconazole (Amistar Top-20\%/12.5\%) were used for pest (Diaphania spp.) and disease (Pseudoperonospora cubensis) control, respectively.

Drip tapes (Petroisa, Avaré, BRA) (500 $\mu \mathrm{m}$ thick and $16 \mathrm{~mm}$ inner diameter) were placed on the surface of the center of each row before mulching. Each drip tape was connected to a $32 \mathrm{~mm}$ diameter polyethylene (PE) pipe. Hand valves controlled the opening and closing of the drip tapes in each plot. The operating pressure was maintained at $100 \mathrm{kPa}$, controlled with a pressure gauge (Petroisa, Avaré, BRA). Each treatment had a soil moisture sensor (model HFM 1000; Falker, Porto Alegre, Brazil) in only one plot. The sensor, previously calibrated for the soil of the area, was installed directly under the drip tape and between two plants at a depth of $20 \mathrm{~cm}$. The soil in the $0-20 \mathrm{~cm}$ layer contains the majority of the roots (Al-Omran et al., 2005; Contreras et al., 2017). The daily reading was taken at 8:00. The amount of water delivered in each irrigation event was determined using Equation 1 (Zhang et al., 2017).

$I D=Z\left(\theta_{F C}-\theta_{a}\right) P / \eta$

where ID is the irrigation depth (mm), $\mathrm{Z}$ is the soil layer depth $(200 \mathrm{~mm}), \theta_{\mathrm{FC}}$ is the soil moisture at field capacity $\left(\mathrm{m}^{3} \mathrm{~m}^{-3}\right), \theta_{\mathrm{a}}$ is the actual soil moisture before irrigation $\left(\mathrm{m}^{3} \mathrm{~m}^{-3}\right), \mathrm{P}$ is the percentage of the wetted zone $(0.50$ or $0.70)$, and $\eta$ is the coefficient of the efficiency of the drip irrigation system.

Table 1: Some selected soil chemical and physical-hydraulic properties.

\begin{tabular}{ccccccccccc}
\hline \multirow{2}{*}{ Cycle } & \multirow{2}{*}{$\mathrm{pH}$} & $\mathrm{P}$ & $\mathrm{K}$ & $\mathrm{S}$ & $\mathrm{Ca}$ & $\mathrm{Mg}$ & Organic matter & Bulk density & $\theta_{\mathrm{FC}}$ & $\theta_{\mathrm{PWP}}$ \\
\cline { 2 - 10 } & & \multicolumn{7}{c}{$\mathrm{mg} \mathrm{dm}^{-3}$} & \multicolumn{7}{c}{$\mathrm{cmol}_{\mathrm{c}} \mathrm{dm}^{-3}$} & $\mathrm{~g} \mathrm{~kg}^{-1}$ & $\mathrm{~g} \mathrm{~cm}^{-3}$ & $\mathrm{~m}^{3} \mathrm{~m}^{-3}$ \\
\hline 1 & 5.8 & 88 & 152 & 35.7 & 4.20 & 0.9 & 32.2 & 1.17 & 0.531 & 0.362 \\
2 & 6.2 & 118 & 242 & 16.8 & 5.72 & 1.0 & 27.1 & 1.09 & 0.495 & 0.337 \\
\hline
\end{tabular}


The field capacity $\left(\theta_{\mathrm{FC}}\right)$ was $0.531 \mathrm{~m}^{3} \mathrm{~m}^{-3}$ in 2017 and $0.495 \mathrm{~m}^{3} \mathrm{~m}^{-3}$ in 2018 at a depth of $20 \mathrm{~cm}$. The coefficient of efficiency of the drip irrigation system determined in a field test ranged from 0.91 to 0.95 . Irrigation was initiated when the soil moisture $\left(\theta_{\mathrm{a}}\right)$ was approximately $0.40 \mathrm{~m}^{3} \mathrm{~m}^{-3}$. The maximum soil water depletion was equal to $30 \%$ of the soil available storage.

In relation to wetted soil percentages (WSPs), two different drip irrigation systems were used to generate two different wetted soil profiles. Then, different emitter discharges and emitter spacings were used (Schwartzman; Zur, 1986). For 50\% WSP, the drip tape had an emitter discharge of $2.3 \mathrm{~L} \mathrm{~h}^{-1}$ and emitter spacing of $50 \mathrm{~cm}$. For $70 \%$ WSP, the drip tape had an emitter discharge of $4.3 \mathrm{~L} \mathrm{~h}^{-1}$ and emitter spacing of $20 \mathrm{~cm}$. After previous irrigations, the WSP was observed through pits in the field and set as $50 \%$ and $70 \%$ for the specific soil layer $(0-20 \mathrm{~cm})$.

Zucchini water consumption was estimated using soil water balance (Equation 2).

$$
W C=I+P-D-R \pm \Delta S
$$

where WC is the zucchini water consumption (mm), I is the irrigation depth $(\mathrm{mm}), \mathrm{P}$ is precipitation $(\mathrm{mm}), \mathrm{D}$ is the drainage flux below the crop root zone $(\mathrm{mm}), \mathrm{R}$ is the surface runoff $(\mathrm{mm})$, and $\Delta \mathrm{S}$ is the change in soil water storage $(\mathrm{mm})$.

In this study, $\mathrm{P}$ was assumed to be effective for the mulched treatments and nonmulched treatments. The drainage (D) below the root zone (Z) was assumed to be negligible because the irrigation amounts applied were small. $\mathrm{R}$ was assumed to be null because the area was flat. $\Delta \mathrm{S}$ was determined by gravimetric measurements, which were taken by sampling the soil moisture before sowing and at harvest in each treatment.

Meteorological data were obtained from a weather station (Irriplus, model E500, Viçosa, BRA) installed close to the experimental area, with data collected every hour. Adigital waterproof thermometer (Dallas Semiconductor, model Ds18b20, Dallas, USA) was installed at a depth of $5 \mathrm{~cm}$ in the soil of each treatment in the three plots. Soil temperature $\left({ }^{\circ} \mathrm{C}\right)$ was recorded during the first three weeks after sowing, when the leaf area index was lowest and there was low soil cover from the plant canopy; this was the period of maximum fluctuation in the soil temperature. Measurements were taken every hour using an Arduino Uno microcontroller.

Net photosynthesis $\left(\mu \mathrm{mol}\right.$ of $\left.\mathrm{CO}_{2} \mathrm{~m}^{-2} \mathrm{~s}^{-1}\right)$ was recorded in the harvest period on October 25, 2017 and April 02, 2018, corresponding to 69 and 43 days after sowing, respectively. The fourth expanded and healthy leaves of three plants in each experimental unit were selected using the central leaf lobe, and net photosynthesis was measured using a portable infrared gas analyzer (LI-COR Biosciences, model LICor 6400, Nebraska, USA). The constant $\mathrm{CO}_{2}$ concentration was $400 \mathrm{ppm}$, and the light intensity was $1200 \mu \mathrm{mol} \mathrm{m} \mathrm{m}^{-2} \mathrm{~s}^{-1}$. This light intensity was chosen based upon a light response curve by choosing the highest net photosynthesis before light saturation (Figure 1).

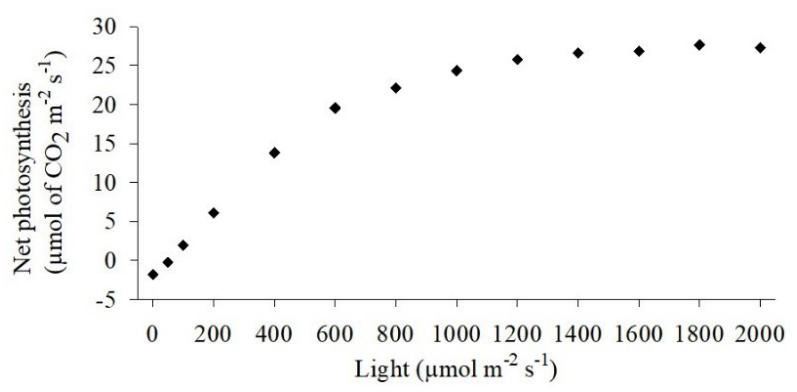

Figure 1: Light curve for a zucchini leaf.

Leaf area was measured by digital photograph analysis using $\mathrm{R}$ software, following the procedures described by Katabuchi (2015). All the leaves of one plant $\left(0.5 \mathrm{~m}^{2}\right)$ in each plot were collected and photographed. Then, the leaf area index was calculated in $\mathrm{m}^{2} \mathrm{~m}^{-2}$.

To quantify weed control in the mulched and nonmulched treatments, the biomass of weeds was measured by collecting and separating the weeds by species. Weeds growing in the hole or piercing the mulch within one $1.0 \mathrm{~m} \times 1.0 \mathrm{~m}$ square in each plot between the 2nd and 3rd zucchini plants in the central row were collected and subsequently dried at $70{ }^{\circ} \mathrm{C}$ for 72 hours. Weed measurements were carried out on two dates in 2017 (September 13 and 28) and in 2018 (March 12 and 22).

Commercial fruit yield $\left(\mathrm{t} \mathrm{ha}^{-1}\right)$ was based on fruit production in the central row in each plot. Fruits approximately $18 \mathrm{~cm}$ long were harvested daily (Carpes et al., 2008). Water-use efficiency $\left(\mathrm{kg} \mathrm{m}^{-3}\right)$ was the ratio between the commercial fruit yield $\left(\mathrm{kg} \mathrm{m}^{-2}\right)$ and amount of water consumed $\left(\mathrm{m}^{3} \mathrm{~m}^{-2}\right)$.

For the soil temperature and net water requirement, a descriptive analysis was adopted. The other variables were analyzed with an F test (analysis of variance), and when there was a significant difference, the means were compared by Tukey's test $(\mathrm{P} \leq 0.050)$. The normality, independence and homoscedasticity of the data were verified. The analysis was performed using $\mathrm{R}$ software (packages "LeafArea" and "ExpDes.pt"). 


\section{RESULTS AND DISCUSSION}

The two consecutive cycles had different climatic conditions (Figure 2). During 2017 (August to October), the total amount of precipitation was $63 \mathrm{~mm}$, the average daily air temperature was $20.9^{\circ} \mathrm{C}$, and the average daily reference evapotranspiration was $3.70 \mathrm{~mm} \mathrm{~d}^{-1}$. During 2018 (February to April), the total amount of precipitation was $335 \mathrm{~mm}$, the average daily air temperature was $24.5^{\circ} \mathrm{C}$, and the average daily reference evapotranspiration was $3.51 \mathrm{~mm} \mathrm{~d}^{-1}$.

In the 2018 cycle, the number of rain events was almost three times (28) that observed in the 2017 cycle (10) (Table 2). The average amount of water per precipitation event was $6.3 \mathrm{~mm}$ in 2017 and $12.0 \mathrm{~mm}$ in 2018. This increased the contribution of water from precipitation to the zucchini water consumption in 2018 compared to that in 2017 (including in the mulched treatments) from (average) $7 \%$ to $60 \%$ (Figure 3). Furthermore, the amount of water was substantially lower in 2018 than in 2017. For the mulched treatments, the zucchini water consumption was equal to $175 \mathrm{~mm}$ and 138 $\mathrm{mm}$ under the white polyethylene mulch (WP), 164 $\mathrm{mm}$ and $145 \mathrm{~mm}$ under the black polyethylene mulch (BP) and $165 \mathrm{~mm}$ and $145 \mathrm{~mm}$ under the biodegradable mulch for the 2017 and 2018 cycles, respectively. In the nonmulched treatment (NM), zucchini water consumption was equal to $239 \mathrm{~mm}$ and $190 \mathrm{~mm}$ in the 2017 and 2018 cycles, respectively. In general, the average water savings in the mulched treatments were 30 and $25 \%$ in the 2017 and 2018 cycles, respectively, compared to the water used in the NM treatment. In relation to the wetted soil percentage (WSP), the zucchini water consumption in the

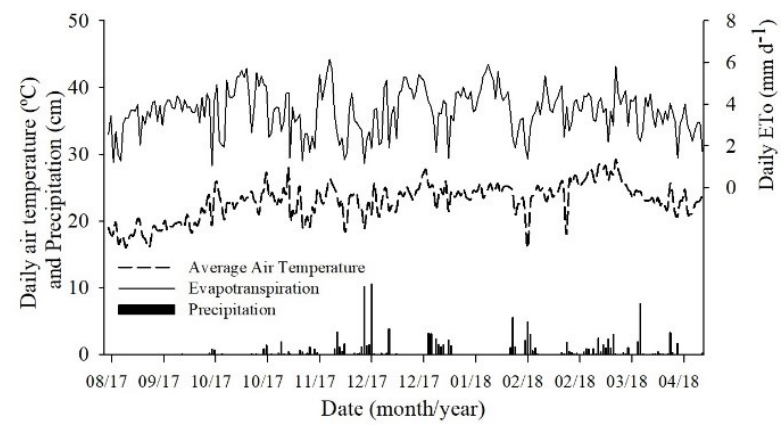

Figure 2: Daily air temperature, reference evapotranspiration (ETo) as determined by the PenmanMonteith equation (indicated by the curves), and daily precipitation (indicated by the bars) during the cropping seasons of 2017 (August 19 to October 31) and 2018 (February 02 to April 16) of zucchini cultivation.

Table 2: Rain and irrigation during the zucchini cropping seasons in each soil mulching treatment (SMT) and wetted soil percentage (WSP) treatment.

\begin{tabular}{|c|c|c|c|c|c|c|}
\hline \multicolumn{3}{|c|}{ Treatments } & \multirow{2}{*}{$\begin{array}{l}\text { Rain } \\
(\mathrm{mm})\end{array}$} & \multirow{2}{*}{$\begin{array}{l}\text { Number of } \\
\text { rain events }\end{array}$} & \multirow{2}{*}{$\begin{array}{l}\text { Number of } \\
\text { irrigation events }\end{array}$} & \multirow{2}{*}{$\begin{array}{l}\text { Cumulative water volume } \\
\text { applied as irrigations (mm) }\end{array}$} \\
\hline Cropping seasons & WSP & SMT & & & & \\
\hline \multirow{8}{*}{2017} & \multirow{4}{*}{$50 \%$} & WP & 63 & 10 & 17 & 165 \\
\hline & & $\mathrm{BP}$ & 63 & 10 & 17 & 152 \\
\hline & & $\mathrm{RP}$ & 63 & 10 & 17 & 156 \\
\hline & & NM & 63 & 10 & 27 & 181 \\
\hline & \multirow{4}{*}{$70 \%$} & WP & 63 & 10 & 18 & 177 \\
\hline & & $\mathrm{BP}$ & 63 & 10 & 18 & 168 \\
\hline & & $\mathrm{RP}$ & 63 & 10 & 18 & 162 \\
\hline & & NM & 63 & 10 & 27 & 213 \\
\hline \multirow{8}{*}{2018} & \multirow{4}{*}{$50 \%$} & WP & 335 & 28 & 8 & 40 \\
\hline & & $\mathrm{BP}$ & 335 & 28 & 8 & 47 \\
\hline & & $\mathrm{RP}$ & 335 & 28 & 5 & 45 \\
\hline & & NM & 335 & 28 & 10 & 88 \\
\hline & \multirow{4}{*}{$70 \%$} & WP & 335 & 28 & 6 & 28 \\
\hline & & $\mathrm{BP}$ & 335 & 28 & 5 & 44 \\
\hline & & $\mathrm{RP}$ & 335 & 28 & 8 & 50 \\
\hline & & NM & 335 & 28 & 10 & 53 \\
\hline
\end{tabular}

WP, white polyethylene mulch; BP, black polyethylene mulch; RP, recycled paper mulch; NM, nonmulched. 
mulched treatments was 7\% (2017) and 5\% (2018) higher under $70 \%$ WSP than under 50\% WSP. However, in the NM treatment, the zucchini water consumption was $20 \%$ (2017) and 17\% (2018) higher in the 70\% WSP treatment than in the $50 \%$ WSP treatment.

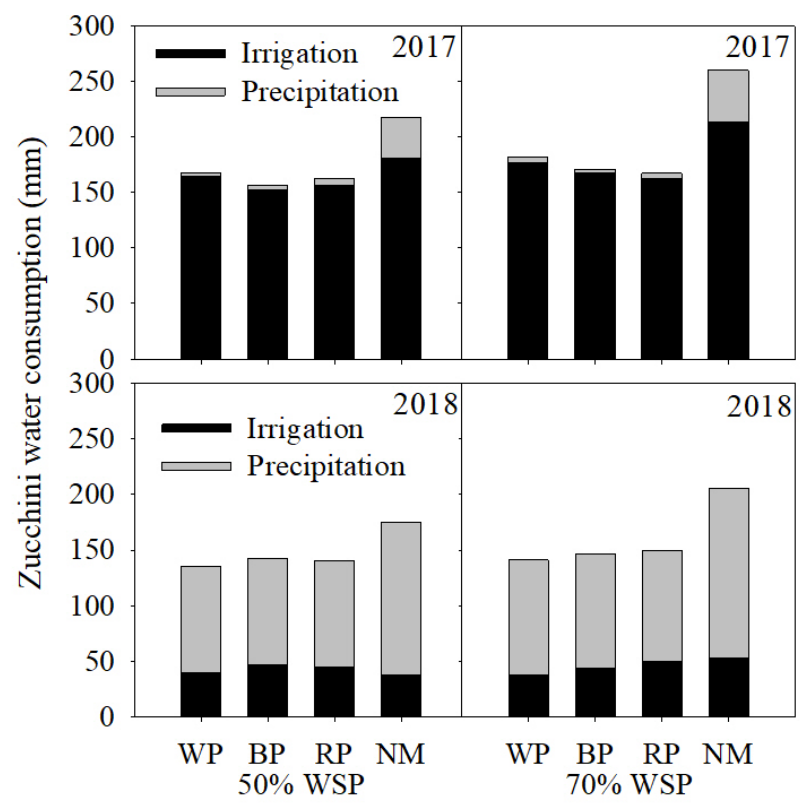

Figure 3: Zucchini water consumption for the different soil mulching treatments: white polyethylene mulch (WP), black polyethylene mulch (BP), recycled paper mulch (RP), nonmulched (NM) and wetted soil percentages: 50\% (P50) and 70\% (P70) for the cropping seasons of 2017 and 2018.

The water consumption and agronomic characteristics of zucchini were greatly influenced by the cropping seasons. Different climatic conditions were observed in each season. Precipitation and air temperature were both lower in 2017 and higher in 2018. In general, the cropping season of 2017 was cold and dry, and the cropping season of 2018 was hot and rainy. Most likely, the climatic conditions (high air temperature) accelerated the zucchini cycle, reducing it from 75 days in 2017 to 57 days in 2018. Due to the duration of the zucchini cycle associated with the climatic condition, the water consumption was lower in 2018 than in 2017.

In the mulched treatments, the biodegradable mulch reduced water consumption more than the polyethylene mulch. Polyethylene mulch can save water by reducing soil evaporation (Liu et al., 2013). Mulch affects soil water contents mainly in the top $0-20 \mathrm{~cm}$ layer (Chen et al., 2019). Water saving under biodegradable mulch depends on its rate of degradation during the cropping season (Chen et al., 2019; Saglam et al., 2017). In this study, the biodegradable mulching material (recycled paper), basically composed of cellulose, was quite resistant to degradation, performing similarly to polyethylene in terms of soil moisture conservation. The resistance to degradation by the recycled paper mulch can be explained by its relatively low water absorption $(33.46 \mathrm{~g}$ of $\left.\mathrm{H}_{2} \mathrm{O} \mathrm{m}^{-2}\right)$ and specific volume $\left(1.42 \mathrm{~cm}^{3} \mathrm{~g}^{-1}\right)$, which indicate a more compact chemical bond between the fibers compared to that in other biodegradable mulches. Slight degradation was observed only along the buried edges, probably caused by soil microorganisms that degrade cellulose.

The soil temperatures under the different soil mulching treatments were affected by the composition of the mulching material employed in both cropping seasons (Figure 4). The soil temperature under the BP was higher in all daylengths during both cropping seasons. The greatest daily thermal amplitude occurred in NM treatment $\left(9.2{ }^{\circ} \mathrm{C}\right.$ in 2017 and $7.3{ }^{\circ} \mathrm{C}$ in 2018). On the other hand, the lowest daily thermal amplitude occurred in the RP treatment $\left(6.0^{\circ} \mathrm{C}\right.$ in 2017 and $3.6^{\circ} \mathrm{C}$ in 2018). The cooling effect of the RP reduced the soil temperature during the hottest hours of the day ( $\sim 15$ hours).

The climatic conditions created by high air temperature associated with solar radiation contributed to increasing the soil temperature. In the cropping season of 2018 , the soil temperature reached $32.3{ }^{\circ} \mathrm{C}$ at 15:00 hours in the BP treatment. Reports have shown that soil temperatures above $30^{\circ} \mathrm{C}$ can interfere negatively with transpiration, photosynthesis and water flow in plants (Amorin; Valle, 1992) and reduce fruit yield (Namaghi et al., 2018). A suitable alternative to reducing soil heat flux is light-colored mulch (such as the RP and WP mulches), especially in tropical climates, such as those found in southeastern Brazil. Light-colored mulch can increase the reflection of solar radiation and reduce soil heat flux and, consequently, soil temperature (Decoteau; Kasperbauer; Hunt, 1990; Ham; Kluitenberg; Lamont, 1993).

In general, the zucchini characteristics were higher in the cropping season of 2017 than in that of 2018 (Table 3). The net photosynthesis (An) was higher in $2017\left(20 \mu \mathrm{mol} \mathrm{CO} \mathrm{m}^{-2} \mathrm{~s}^{-1}\right)$ than in $2018(19 \mu \mathrm{mol}$ $\mathrm{CO}_{2} \mathrm{~m}^{-2} \mathrm{~s}^{-1}$ ). Furthermore, the leaf area index (LAI) was much higher $(27 \%)$ in $2017\left(2.98 \mathrm{~m}^{2} \mathrm{~m}^{-2}\right)$ than in 2018 $\left(2.34 \mathrm{~m}^{2} \mathrm{~m}^{-2}\right)$. The zucchini plants yielded 96.3 ton $\mathrm{ha}^{-1}$ in 
2017 and 36.9 ton ha $^{-1}$ in 2018. The water-use efficiency (WUE) was higher in $2017\left(53.9 \mathrm{~kg} \mathrm{~m}^{-3}\right)$ than in 2018 $\left(35.1 \mathrm{~kg} \mathrm{~m}^{-3}\right)$. The weeds growing in the area, measured by weed dry mass (WDM), were similar in both cropping seasons. However, the amount of weeds growing in the NM treatment $\left(32.9 \mathrm{~g} \mathrm{~m}^{-2}\right)$ was substantially higher than that in the mulched treatments (i.e., WP, BP and RP) $\left(1.5 \mathrm{~g} \mathrm{~m}^{-2}\right.$, on average). Furthermore, weed control in the RP treatment $\left(2.1 \mathrm{~g} \mathrm{~m}^{-2}\right)$ was comparable to that in the polyethylene mulch treatments (WP, $1.2 \mathrm{~g} \mathrm{~m}^{-2}$; BP, $1.4 \mathrm{~g} \mathrm{~m}^{-2}$ ). The LAI was much higher $(150 \%)$ in the mulched treatments than in the NM treatment. The soil mulching treatments greatly influenced

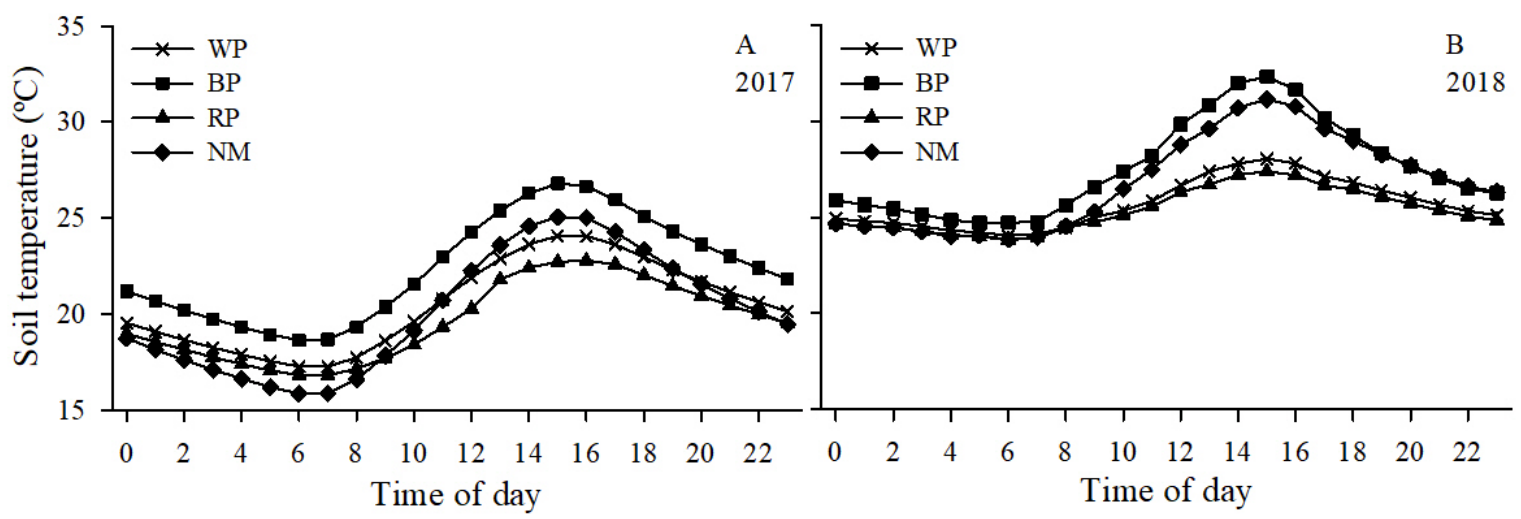

Figure 4: Soil temperature at $5 \mathrm{~cm}$ beneath the soil mulching treatment in the cropping seasons of $2017(\mathrm{~A})$ and 2018 (B). WP, white polyethylene; BP, black polyethylene; RP, recycled paper and NM, nonmulched. The data shown represent the average of the first three weeks.

Table 3: Tukey test for the effects of the cropping seasons (S), soil mulching materials $(M)$ and wetted soil percentages (P) on the net photosynthesis (An), leaf area index (LAl), fruit yield (Yield), water-use efficiency (WUE) of zucchini and weed dry mass (WDM).

\begin{tabular}{|c|c|c|c|c|c|c|}
\hline Treatment & & $\begin{array}{c}\text { An }(\mu \mathrm{mol} \\
\left.\mathrm{CO}_{2} \mathrm{~m}^{-2} \mathrm{~s}^{-1}\right)\end{array}$ & $\begin{array}{c}\mathrm{LAI} \\
\left(\mathrm{m}^{2} \mathrm{~m}^{-2}\right) \\
\end{array}$ & $\begin{array}{c}\text { Yield } \\
\text { (ton ha-1) }^{-1}\end{array}$ & $\begin{array}{c}\text { WUE } \\
\left(\mathrm{kg} \mathrm{m}^{-3}\right)\end{array}$ & $\begin{array}{l}\text { WDM } \\
\left(\mathrm{g} \mathrm{m}^{-2}\right)\end{array}$ \\
\hline \multirow{2}{*}{ Cropping season (S) } & 2017 & $20.0 a$ & $2.98 \mathrm{a}$ & $96.3 a$ & $53.9 \mathrm{a}$ & 1.38 \\
\hline & 2018 & $19.0 \mathrm{~b}$ & $2.34 \mathrm{~b}$ & $36.9 \mathrm{~b}$ & $25.1 \mathrm{~b}$ & 1.36 \\
\hline \multirow{4}{*}{$\begin{array}{l}\text { Soil mulching } \\
\text { material (M) }\end{array}$} & WP & 19.4 & $3.06 \mathrm{a}$ & $78.1 \mathrm{a}$ & $49.6 \mathrm{a}$ & $0.62 \mathrm{~b}$ \\
\hline & $\mathrm{BP}$ & 19.7 & $3.01 \mathrm{a}$ & $69.1 \mathrm{ab}$ & $44.0 \mathrm{ab}$ & $0.64 \mathrm{~b}$ \\
\hline & $\mathrm{RP}$ & 19.9 & $2.63 \mathrm{a}$ & $66.6 \mathrm{~b}$ & $41.3 \mathrm{~b}$ & $0.89 \mathrm{~b}$ \\
\hline & NM & 19.1 & $1.93 \mathrm{~b}$ & $52.4 \mathrm{c}$ & $23.2 \mathrm{c}$ & $3.35 \mathrm{a}$ \\
\hline \multirow{2}{*}{$\begin{array}{c}\text { Wetted soil } \\
\text { percentage (P) }\end{array}$} & P50 & 19.3 & 2.63 & 67.4 & $41.6 \mathrm{a}$ & 1.36 \\
\hline & P70 & 19.7 & 2.69 & 65.9 & $37.4 \mathrm{~b}$ & 1.39 \\
\hline \multicolumn{7}{|c|}{$p$-value } \\
\hline $\mathrm{S}$ & & $0.0211 *$ & $<0.0001^{*}$ & $<0.0001 *$ & $<0.0001 *$ & $0.8628^{\text {ns }}$ \\
\hline M & & $0.5891^{\text {ns }}$ & $<0.0001 *$ & $<0.0001 *$ & $<0.0001 *$ & $<0.0001$ * \\
\hline $\mathrm{P}$ & & $0.4288^{\text {ns }}$ & $0.7249^{n s}$ & $0.6236^{n s}$ & $0.0173 *$ & $0.7768^{\text {ns }}$ \\
\hline SxM & & $0.5257^{\mathrm{ns}}$ & $0.5337^{\mathrm{ns}}$ & $0.5214^{\mathrm{ns}}$ & $0.0978^{\text {ns }}$ & $0.1026^{\mathrm{ns}}$ \\
\hline SxP & & $0.4451^{\mathrm{ns}}$ & $0.6011^{\mathrm{ns}}$ & $0.1521^{\mathrm{ns}}$ & $0.5183^{\text {ns }}$ & $0.5669^{\text {ns }}$ \\
\hline $\mathrm{M} \times \mathrm{P}$ & & $0.7072^{\text {ns }}$ & $0.1697^{\mathrm{ns}}$ & $0.0806^{\mathrm{ns}}$ & $0.1421^{\text {ns }}$ & $0.3887^{\text {ns }}$ \\
\hline SxMxP & & $0.8868^{\text {ns }}$ & $0.4625^{\text {ns }}$ & $0.1856^{\mathrm{ns}}$ & $0.2011^{\mathrm{ns}}$ & $0.7886^{\text {ns }}$ \\
\hline
\end{tabular}

${ }^{1}$ The data were transformed by $\ln (x+1)$ to meet the normality criterion. In each column, the means followed by the same lowercase letter do not differ based on Tukey's test at $P \leq 0.050$. * and ns mean the results were significant and not significant, respectively, based on the $\mathrm{F}$ test at $P \leq 0.050$. 
fruit production, with yields of 78.1 ton $\mathrm{ha}^{-1}$ in the WP treatment, 69.1 ton $\mathrm{ha}^{-1}$ in the BP treatment, 66.6 ton ha ${ }^{-1}$ in the RP treatment and 52.4 ton $\mathrm{ha}^{-1}$ in the NM treatment. The WUE was higher in the mulched treatments than in the NM treatment. The wetted soil percentages influenced only the WUE, which was higher in the $50 \%$ treatment $(41.6 \mathrm{~kg}$ $\left.\mathrm{m}^{-3}\right)$ than in the $70 \%$ treatment $\left(37.4 \mathrm{~kg} \mathrm{~m}^{-3}\right)$.

The rate of photosynthesis is affected by thermal and water stresses (Amorin; Valle, 1992; El-Mageed; Semida; El-Wahed, 2016; Mu; Fang, 2017). Most likely, the higher soil temperature in 2018 negatively affected the net photosynthesis compared to that in 2017. Moreover, in 2017, the yield was 2.6 times higher than that in 2018. This result can be explained by the larger leaf area in 2017 associated with higher daily solar radiation and longer cycle duration compared to those in 2018 . The average daily solar radiation was $239 \mathrm{~W} \mathrm{~m}^{-2}$ in 2017 and $205 \mathrm{~m}^{-2}$ in 2018 . The duration of the zucchini cycle was 75 days in 2017 and 57 days in 2018. Plant growth and fruit yield are closely linked to the amount of photosynthetically active radiation (PAR; $400-700 \mathrm{~nm}$ ) intercepted by leaves, and LAI is frequently used for quantifying the intercepted PAR (Ewert, 2004). Furthermore, compared with the recommended range (18 to $24{ }^{\circ} \mathrm{C}$ ), the fluctuations in air temperature were more suitable for zucchini in 2017 than in 2018 (Fontes, 2005). The combination of these factors may have resulted in more carbohydrate production and consequently more fruit production.

Mulching is an appropriate agricultural technique for water saving. Reports have shown an increase in wateruse efficiency (WUE) in many crops, such as pumpkin (Brust, 2000), squash (El-Mageed; Semida; El-Wahed, 2016), potato (Zhang et al., 2017), sorghum (El-Mageed et al., 2018) and cucumber (Yaghi; Arslan; Naoum, 2013). Mulches conserve soil moisture and reduce soil evaporation, improving plant water status (El-Mageed et al., 2018). Soil water evaporation is generally not useful for increasing crop yield (Xie; Wang; Li, 2005). In this study, a low wetted soil percentage $(50 \%)$ increased the WUE, which is consistent with results in potato crops (Zhang et al., 2017).

The abundance of five predominant species of weeds was different for the soil mulching treatments and cropping seasons (Figure 5). In general, the weeds Cyperus rotundus (35\%) and Oxalis latifolia (39\%) were more abundant in the mulched treatments (RP, WP and BP), while C. rotundus $(37 \%)$ and Amaranthus viridis (33\%) were more abundant in the NM treatment. The percentage of $C$. rotundus increased from $2017(27 \%)$ to $2018(46 \%)$ in all the treatments. On the other hand, the percentage of the weeds Emilia sonchifolia, A. viridis and Sorghum halepense decreased substantially from 2017 to 2018 in the mulched treatments.

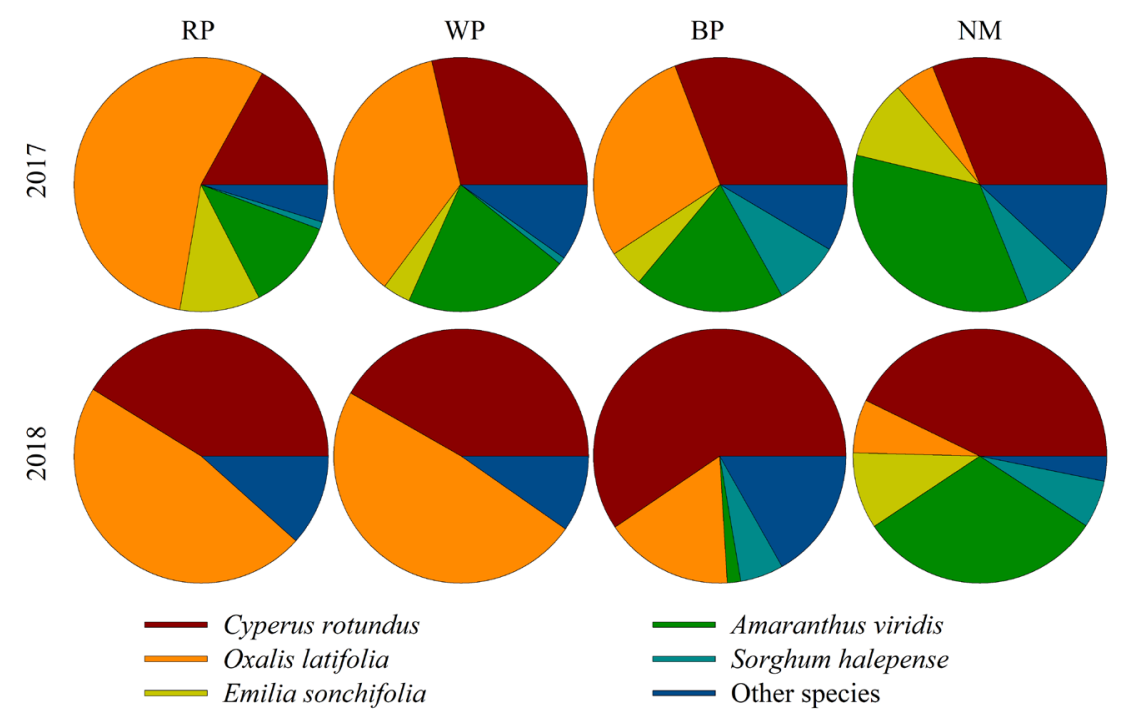

Figure 5: Pie chart of the relative abundances of the weeds (dry mass $\left(\mathrm{g} \mathrm{m}^{-2}\right)$ ) in the zucchini plots grown with different soil mulching treatments: white polyethylene mulch (WP), black polyethylene mulch (BP), biodegradable mulch of recycled paper (RP), and nonmulched (NM) for the cropping seasons of 2017 and 2018. 
The yield was much higher in the mulched treatments than in the NM. Mulch can increase surface reflectance (Decoteau; Kasperbauer; Hunt, 1990; Ham; Kluitenberg; Lamont, 1993), contributing to the efficiency of light absorption by chlorophyll and consequently increasing fruit yield (Brust, 2000; Olinik et al., 2011). Mulch is important for weed control (Coleman et al., 2015). Weeds compete for water, nutrients, light and space, which can lead to a loss of productivity. In this study, the predominant weed was Cyperus rotundus, a perennial, aggressive and difficult-to-control weed (Kumar, 2016), considered the most problematic in cucurbit crops (Coleman et al., 2015). In general, the biodegradable mulch (RP) was comparable to the polyethylene mulch in terms of weed control; therefore, it is a suitable alternative that could replace polyethylene mulch. These results represent useful information for farmers and technicians regarding the use of mulches. Furthermore, curiously, $C$. rotundus and Oxalis latifolia were the predominant weeds in the mulched treatments. These weeds have in common a reserve structure that provides energy for the growth/ development of the plant, allowing it to find sunlight through the mulch hole.

\section{CONCLUSIONS}

In this study, the cropping season, soil mulching treatment and wetted soil percentage significantly influenced the zucchini water consumption and agronomic characteristics. The biodegradable mulch was comparable to the polyethylene mulch in terms of water savings. The cropping season of 2017 was more favorable for zucchini than the 2018 season, resulting in higher leaf area growth, net photosynthesis, fruit yield and water-use efficiency. On average, the mulch reduced water consumption by $30 \%$ in 2017 and $25 \%$ in 2018 . The zucchini water consumption was equal to $175 \mathrm{~mm}$ and $138 \mathrm{~mm}$ under the white polyethylene mulch, $164 \mathrm{~mm}$ and $145 \mathrm{~mm}$ under the black polyethylene mulch, $165 \mathrm{~mm}$ and 145 $\mathrm{mm}$ under the biodegradable mulch and $239 \mathrm{~mm}$ and 190 $\mathrm{mm}$ in the nonmulched treatment in the cropping seasons of 2017 and 2018, respectively. Soil temperature and its amplitude were reduced under the biodegradable and white polyethylene mulches, so both are suitable alternatives to traditional mulches in tropical climates. Compared to the nonmulched treatment, the mulch treatments were efficient in saving water, reducing weed infestations (95\%), increasing yield (36\%) and enhancing water-use efficiency (94\%). Compared to the $70 \%\left(37.4 \mathrm{~kg} \mathrm{~m}^{-3}\right)$ wetted soil percentage, the $50 \%\left(41.6 \mathrm{~kg} \mathrm{~m}^{-3}\right)$ treatment increased the water-use efficiency. Compared to the polyethylene mulch, C. rotundus and other weeds were better controlled by the biodegradable mulch. In general, these results represent useful information that extends the options for technicians and farmers.

\section{ACKNOWLEDGEMENTS}

The authors are grateful to the Brazilian National Council for Scientific and Technological Development (CNPq), scholarship grant 434484/2018-0, to the Coordination for the Improvement of Higher Education Personnel (Capes), Finance code 001, and especially to Professor Silvio Bueno Pereira (in memory) (DEA-UFV) for his scientific support.

\section{REFERENCES}

AHOKAS, J. et al. Paper based mulches as an alternative to polyethylene mulch in vegetable production. Makinaları Bilimi Dergisi, 10(1):73-78, 2014.

AL-OMRAN, A. M. et al. Effect of drip irrigation on squash (Cucurbita pepo) yield and water-use efficiency in sandy calcareous soils amended with clay deposits. Agricultural Water Management, 73(1):43-55, 2005.

ALVARES, C. A. et al. Köppen's climate classification map for Brazil. Meteorologische Zeitschrift, 22(6):711-728, 2013.

AMORIN, S. M. C. de; VALLE, R. R. Radicular temperature effects in water movement resistence in cacao tree (Theobroma cacao L.). Acta Botanica Brasilica, 6(1):55-64, 1992.

BISWAS, S. K. et al. Effect of drip irrigation and mulching on yield, water-use efficiency and economics of tomato. Plant, Soil and Environment, 61(3):97-102, 2015.

BRAULT, D.; STEWART, K. A.; JENNI, S. Growth, development, and yield of head lettuce cultivated on paper and polyethylene Mulch. HortScience, 37(1):92-94, 2002.

BRUST, G. E. Reflective and black mulch increase yield in pumpkins under virus disease pressure. Journal of Economic Entomology, 93(3):828-833, 2000.

CARPES, R. H. et al. Ausência de frutos colhidos e suas interferências na variabilidade da fitomassa de frutos de abobrinha italiana cultivada em diferentes sistemas de irrigação. Ceres, 55(6):590-595, 2008.

CHEN, B. et al. Two-dimensional monitoring of soil water content in fields with plastic mulching using electrical resistivity tomography. Computers and Electronics in Agriculture, 159:84-91, 2019. 
CHEN, Y. et al. Empirical estimation of pollution load and contamination levels of phthalate esters in agricultural soils from plastic film mulching in China. Environmental Earth Sciences, 70(1):239-247, 2013.

CIRUJEDA, A. et al. Biodegradable mulch instead of polyethylene for weed control of processing tomato production. Agronomy for Sustainable Development, 32(4):889897, 2012.

COLEMAN, M. J. et al. Survey of weed impact, management, and research priorities in Australian cucurbit production. Plant Protection Quarterly, 30(1):12-20, 2015.

CONTRERAS, J. I. et al. Irrigation management of greenhouse zucchini with different soil matric potential level. Agronomic and environmental effects. Agricultural Water Management, 183:26-34, 2017.

DECOTEAU, D. R.; KASPERBAUER, M. J.; HUNT, P. G. Bell pepper plant development over mulches of diverse colors. HortScience, 25(4):460-462, 1990.

EL-MAGEED, T. A. A. et al. Compost and mulching modulates morphological, physiological responses and water use efficiency in sorghum (bicolor L. Moench) under low moisture regime. Agricultural Water Management, 208:431-439, 2018.

EL-MAGEed, T. A. A.; SEMIDA, W. M.; EL-WAHED, M. H. A. Effect of mulching on plant water status, soil salinity and yield of squash under summer-fall deficit irrigation in salt affected soil. Agricultural Water Management, 173:1-12, 2016.

EL-SAMNOUDI, I. M. et al. Combined effect of poultry manure and soil mulching on soil properties, physiological responses, yields and water-use efficiencies of sorghum plants under water stress. Communications in Soil Science and Plant Analysis, 50(20):2626-2639, 2019.

EWERT, F. Modelling plant responses to elevated $\mathrm{CO}_{2}$ : How important is leaf area index? Annals of Botany, 93(6):619$627,2004$.

FAN, Y. et al. Plastic mulch decreases available energy and evapotranspiration and improves yield and water use efficiency in an irrigated maize cropland. Agricultural Water Management, 179:122-131, 2017.

FEDDES, R. A. et al. Simulation of field water uptake by plants using a soil water dependent root extraction function. Journal of Hydrology, 31(1):13-26, 1976.

FONTES, P. C. R. Olericultura teoria e prática. Viçosa: Editora UFV, 2005. 486p.
GRECCO, K. L. et al. HYDRUS-2D simulations of water and potassium movement in drip irrigated tropical soil container cultivated with sugarcane. Agricultural Water Management, 221:334-347, 2019

GROSS, R. A.; KALRA, B. Biodegradable polymers for the environment. Science, 297:803-807, 2002.

HAM, J. M.; KLUITENBERG, G. J.; LAMONT, W. J. Optical properties of plastic mulches affect the field temperature regime. Journal of the American Society for Horticultural Science, 118(2):188-193, 1993.

HOU, F. et al. Mulching with plastic film improved the root quality of summer-sown sweet potato (Ipomoea batatas (L). Lam.) in northern China. Journal of Integrative Agriculture, 18(5):982-991, 2019.

KASIRAJAN, S.; NGOUAJIO, M. Polyethylene and biodegradable mulches for agricultural applications: A review. Agronomy for Sustainable Development, 32(2):501529, 2012.

KATABUCHI, M. Leaf area: An R package for rapid digital image analysis of leaf area. Ecological Research, 30(6):1073$1077,2015$.

KELLER, J.; KARMELI, D. Trickle irrigation design parameters. Transactions of the ASAE, 17(4):678-684, 1974.

KUMAR, V. Importance of Motha (Cyperus rotundus Linn.) and its control management. Van Sangyan, 3(5):37-43, 2016.

KUSLU, Y. et al. Fruit yield and quality, and irrigation water use efficiency of summer squash drip-irrigated with different irrigation quantities in a semi-arid agricultural area. Journal of Integrative Agriculture, 13(11):25182526, 2014.

LIU, E. K.; HE, W. Q.; YAN, C. R. 'White revolution' to 'white pollution' - Agricultural plastic film mulch in China. Environmental Research Letters, 9:99-101, 2014.

LIU, M. X. et al. Numerical simulation of soil water dynamics in a drip irrigated cotton field under plastic mulch. Pedosphere, 23(5):620-635, 2013.

MILES, C. et al. Deterioration of potentially biodegradable alternatives to black plastic mulch in three tomato production regions. HortScience, 47(9):1270-1277, 2012.

MU, L.; FANG, L. Effects of different mulching practices on the photosynthetic characteristics of hot pepper (Capsicum annuum L.) in a greenhouse in Northwest China. Acta Agriculturae Scandinavica, Section B - Soil \& Plant Science, 65(8):735-746, 2017. 
NAMAGHI, M. N. et al. Effects of mulching on soil temperature and moisture variations, leaf nutrient status, growth and yield of pistachio trees (Pistacia vera .L). Scientia Horticulturae, 241:115-123, 2018.

OLINIK, J. et al. Produtividade de híbridos de abobrinha italiana cultivados sob diferentes coberturas de solo. Horticultura Brasileira, 29(1):130-134, 2011.

PROHORT. Programa Brasileiro de Modernização do Mercado Hortigranjeiro - PROHORT. 2019. Available in: <http://dw.ceasa.gov.br/>. Access in: September, 16, 2019.

QIN, S. et al. Can the drip irrigation under film mulch reduce crop evapotranspiration and save water under the sufficient irrigation condition? Agricultural Water Management, 177:128-137, 2016.

RIBAS, G. G. et al. Temperatura do solo afetada pela irrigação e por diferentes coberturas. Engenharia Agrícola, 35(5):817828, 2015.

SAGLAM, M. et al. Modeling the effect of biodegradable paper and plastic mulch on soil moisture dynamics. Agricultural Water Management, 193:240-250, 2017.

SARAIVA, A. et al. The use of biodegradable mulch films in muskmelon crop production. Journal of Agricultural Science and Review, 1(4):88-95, 2012.
SCHWARTZMAN, M.; ZUR, B. Emitter spacing and geometry of wetted soil volume. Journal of Irrigation and Drainage Engineering, 112(3):242-253, 1986.

TEIXEIRA, P. C. et al. Manual de Métodos de Análise de Solo. Brasília: Embrapa, 2017. 574p.

VICENTE, M. R. et al. Spacial distribution of fertigated coffee root system. Ciência e Agrotecnologia, 41(1):72-80, 2017.

WORTMAN, S. E.; KADOMA, I.; CRANDALL, M. D. Biodegradable plastic and fabric mulch performance in field and high tunnel cucumber production. HortTechnology, 26(2):148-155, 2016.

XIE, Z.; WANG, Y.; LI, F. Effect of plastic mulching on soil water use and spring wheat yield in arid region of northwest China. Agricultural Water Management, 75:71-83, 2005.

YAGHI, T.; ARSLAN, A.; NAOUM, F. Cucumber (Cucumis sativus, L.) water use efficiency (WUE) under plastic mulch and drip irrigation. Agricultural Water Management, 128:149157, 2013.

YANG, N. et al. Plastic film mulching for water-efficient agricultural applications and degradable films materials development research. Materials and Manufacturing Processes, 30(2):143-154, 2015.

ZHANG, Y. L. et al. Influence of different plastic film mulches and wetted soil percentages on potato grown under drip irrigation. Agricultural Water Management, 180:160-171, 2017. 